\title{
Effects of Laryngeal Massage and Semi-occluded Vocal Tract Exercises for Patients with Hyperfunctional Dysphonia
}

\author{
Ji-Sung Kim ${ }^{\mathrm{a}, \mathrm{b}}$, Dong-Wook Lee ${ }^{\mathrm{c}}$, Chul-Hee Choi ${ }^{\mathrm{d}}$, Seong Hee Choi ${ }^{\mathrm{d}}$ \\ ${ }^{a}$ Graduate School of Health Sciences, Daegu Catholic University, Gyeongsan, Korea \\ ${ }^{b}$ Department of Otorhinolaryngology, Chungbuk National University Hospital, Choengju, Korea \\ 'Department of Otorhinolaryngology-Head and Neck Surgery, Chungbuk National University College of Medicine, Cheongju, Korea \\ ${ }^{d}$ Department of Audiology and Speech-Language Pathology, Daegu Catholic University, Gyeongsan, Korea
}

\author{
Correspondence: Seong Hee Choi, $\mathrm{PhD}$ \\ Department of Audiology and Speech-Language \\ Pathology, Daegu Catholic University, 13-13 \\ Hayang-ro, Hayang-eup, Gyeongsan 38430, Korea \\ Tel: $+82-53-850-2542$ \\ Fax: $+82-53-850-2540$ \\ E-mail: shgrace@cu.ac.kr \\ Received: October 3, 2017 \\ Revised: November 18, 2017 \\ Accepted: November 27, 2017 \\ This work is supported by research grants from \\ the Daegu Catholic University.
}

\begin{abstract}
Objectives: High laryngeal position, pharyngeal constriction, laryngeal and neck tension, excessive supraglottic compression, and vocal fold closure are common characteristics associated with hyperfunctional dysphonia. The purpose of this study was to investigate the effects of voice therapy consisting of laryngeal massage and semi-occluded vocal tract exercises (SOVTE) in patients with hyperfunctional dysphonia and following voice therapy adherence. Methods: Twenty-eight patients with hyperfunctional voice disorders diagnosed with muscle tension dysphonia, vocal nodules, and vocal polyp were treated with voice therapy once using laryngeal massage and SOVTE: lip trills, humming, bilabial fricative [b:], straw phonation. They completed acoustic and auditory-perceptual assessment before and after voice therapy. Results: Significant immediate effects were observed in STD (standard deviation of F0), Jitter, Shimmer, NHR (noise to harmonic ratio), vAm (peak to peak amplitude variation), vFO (fundamental frequency variation), ATRI (Amplitude Tremor Intensity Index), FTRI (F0 Tremor Intensity Index), PPQ (pitch perturbation quotient), APQ (amplitude perturbation quotient), DSH (degree of sub-harmonic), VTI (Voice Turbulence Index), DUV (degree of voiceless) and ' $G$ ', ' $R$,' 'B' in the GRBAS scale and most of the patients continued with voice therapy. Conclusion: Laryngeal massage and SOVTE may provide immediate advantages in hyperfunctional dysphonia and have a positive effect on voice therapy adherence.
\end{abstract}

Keywords: Laryngeal massage, SOVTE, Hyperfunctional voice, Voice therapy adherence
높은 후두 위치, 인두 협착, 상후두의 과도한 수축이나 성대내전 은 과기능 음성장애의 일반적인 특징으로서 높은 후두 위치는 후 두와 목 주변의 근긴장을 유발하며, 외후두근의 과도한 근긴장은 과기능 음성장애의 원인이 될 수 있다(Guzman, Castro, Testart, Muñoz, \& Gerhard, 2013).

후두의 위치를 낮추고 인두강을 확장시키며, 강한 성대 접촉을 줄일 수 있는 음성치료 방법으로 하품-한숨기법, 후두마사지, 이완, 구강개방법, 부드러운 발성 시작과 같은 여러가지 음성촉진기법이 사용되어 왔다(Boone, McFarlane, \& Von Berg, 2007).

이러한 촉진 치료기법들 가운데 후두마사지는 조음기관 근육과
후두내외근을 포함한 성도 전체에 영향을 미칠 수 있는 후두근육 의 과긴장을 이완시키는 방법으로 과기능적 음성장애 환자에게 효 과적으로 사용되고 있다(Aronson, 1990; Mathieson et al., 2009; Roy, 2008; Roy \& Leeper, 1993; Roy, Bless, Heisey, \& Ford, 1997). 가장 널리 쓰이는 후두마사지법은 manual circumlaryngeal therapy (MCT)와 laryngeal manual therapy (LMT)로 두 방법 모두 설 골과 갑상설골막, 설골상부 위를 원을 그리듯 중재하지만, LMT는 흥쇄유돌근의 이완을 목표로 한 손이나 양손을 사용하여 후두근 육의 이완 후 발성을 유도하는 반면 MCT는 설골의 이완을 목표로 한 손을 사용하며 마사지 동안 발성을 유도한다는 차이가 있다 
(Mathieson et al., 2009).

한편, 반폐쇄성도훈련(semi-occluded vocal tract exercise, SOVTE) 은 음성산출 메커니즘의 조직적 손상 없이 정상음성을 산출하는 것을 목표로 하는 경제지향적인 음성훈련방법으로(Titze, 2006), 성대 진동과 성대 접촉의 충격이 감소되면 성대 손상을 최소화할 수 있다는 것을 전제로 한다(Berry et al., 2001). SOVTE는 성도의 일부를 수축하는 것으로, 성도의 앞 혹은 뒤의 반폐쇄는 성문상압 이 성문내부의 압력과 기류를 증가시키도록 만들어 성도가 주파수 에 해당하는 음들을 선택하여 강화시키는 전통적인 여과기의 역할 을 하는 것이 아니라 음원과 여과기 사이의 상호작용을 통해 더 많 은 공기역학적 에너지를 음향학적 에너지로 변화시키도록 감각 피 드백의 역할을 한다는 비선형 음원-여과기 이론으로 설명된다(Choi, 2017; Titze, 2006). 입술이나 혀 트릴, 허밍, 빨대 혹은 튜브 발성과 같은 반폐쇄성도운동 시, 성문하압과 성문 사이의 상호작용이 증 가 될 수 있는데 이러한 상호작용은 음성의 강도를 증가시키기 때 문에 음성의 경제성을 유지할 수 있게 한다(Berry et al., 2001). 또 한, SOVTE 시 후두 위치는 하강되고, 인두는 넓어지며, 후두 전후 의 압축은 이완되는데(Guzman et al., 2013), 이는 구강 내 압력의 변화로 인해 성도와 성대가 마치 마사지되는 것 같은 마사지 효과 를 가져오기 때문이다(Radolf, Laukkanen, Horáček, \& Liu, 2014).

후두마사지와는 달리, 직접적인 음성치료법 중 호흡, 발성, 공명 의 협응에 초점을 맞춘 총체적 음성치료(holistic voice therapy)인 SOVTE는 크게 성도에서 진동하는 진동원의 수에 따라 손으로 입 가리기, 허밍, 빨대발성과 같은 단일 진동원과 Lax Vox, 입술 또는 혀 트릴과 같은 이중 진동원으로 나눌 수 있다(Choi, 2017; Titze, 2006). 또 다른 형태의 SOVTE인 양순마찰음[ㅂ:]은 핀란드어에 속 한 음소로 한국어나 영어의 음소에는 없지만, 산출하기 쉽고 입술 이 난기류를 생성하기 위해 충분히 근접해야 된다는 반폐쇄의 기 준에 부합하는 SOVTE의 한 유형(Laukkanen, 1992; Laukkanen, Lindholm, Vilkman, Haataja, \& Alku, 1996)으로 이후 빨대저항발 성(flow resistant straws)으로 확대되었다(Titze, 2002a).

이처럼, SOVTE는 성악가의 발성 워밍이나 과기능적 음성장애 에 환자에게 매우 유용한 음성치료 방법으로 사용될 수 있으며, 과 거나 현재 후두 병변이 없는 성악가들에게 즉각적인 목소리 개선 효과가 있는 것으로 보고되었다(Fadel et al., 2016). 또한, 최근 성대 병변이 관찰되지 않는 과기능 음성장애환자(Guzman et al., 2013) 를 대상으로 SOVTE의 음성치료 효과를 보고한 연구가 있으나, 성 대 결절이나 용종과 같이 병변이 있는 과기능 음성장애 환자에 대 한 효과는 미흡하다.

이러한 과기능 음성장애 환자들은 일반적으로 음성언어재활사
에 의해 음성치료를 가장 많이 시행하는 환자군임에도 불구하고 (Choi, 2013), 음성치료를 중단하거나 음성치료를 받지 않는 경우가 많다.

음성문제로 인해 이비인후과 내원 후 음성치료를 받은 환자들은 음성치료에 대해 $84.3 \%$ 의 높은 만족도를 보일 만큼 음성치료는 음 성장애의 치료에 효과적인 방법이다. 하지만, 음성치료에 대한 낮은 사회적 인식과 약물치료나 수술치료를 해야 된다는 선입견적 상식, 가시적으로 보이지 않는 발성기관의 운동성 조절이 음성개선을 가 져온다는 음성치료에 대한 이해와 신뢰감 부족 때문에 음성치료를 권고 받은 환자 중 $26.3 \%$ 는 치료를 중도 포기하거나 종결하지 못하 는 경우도 있다(Ahn, Shin, \& Shin, 2016). 따라서, 음성치료에 있어 적절한 치료기법의 적용과 환자의 협조만큼이나 음성치료와 치료 사에 대한 신뢰감 형성은 성공적인 음성치료를 위한 중요한 요소라 고 할 수 있겠다. 또한, 음성치료를 지속하기 위해서는 음성치료 결 과에 대한 기대, 환자의 음성치료에 대한 동기나 신념, 자신의 음성 을 변화시킬 수 있다고 믿는 환자의 자신감 등 환자의 신념이나 관 점이 매우 중요한 영향을 미치는 것으로 보고되었다(Van Leer \& Conner, 2010).

따라서, 본 연구는 SOVTE가 시각적, 촉각적 감각 피드백을 증가 시켜 과기능 음성장애 환자에게 동기를 부여함으로써 즉각적인 음 성변화가 있는지 살펴보고 이러한 음성변화가 추후 음성치료에 미 치는 영향을 살펴보고자 한다.

\section{연구방법}

\section{연구대상}

본 연구의 대상자는 2016년 7월부터 2017년 7월까지 음성문제를 호소로 대학병원 이비인후과를 내원하여 후두내시경상 성대에 기 질적 문제는 없으나, 성문상부의 압축이나 가성대 발성과 같은 과 긴장이 동반되고, 상기도 감염 시 발생된 음성문제가 지속된 특징 을 보이는 근긴장성발성장애와 양성 성대점막질환으로 진단받은 환자이다. 대상자들은 남성 8 명과 여성 20 명 총 28 명이며, 평균연령 은 $47.9 \pm 14.2$ 세로 인후두역류 질환과 호흡기 질환이 없고 난청과 신경학적 문제가 없었다. 그룹별 대상자들의 성별과 연령별 분포는 Table 1과 같다.

\section{음성치료프로그램}

\section{후두마사지}

후두마사지는 설골 뒤편, 갑상연골 막 앞쪽, 갑상연골 뒤쪽 융기 와 설골상근 및 설골하근 촉진 후 4 점 척도로 후두과긴장을 평가 
Table 1. Participants' information ( $\mathrm{N}=28)$

\begin{tabular}{lc}
\hline Characteristic & Value \\
\hline Age (yr) & $47.9 \pm 14.2$ \\
Diagnosis & \\
Muscle tension dysphonia (M/F) & $14(4 / 10)$ \\
Vocal nodules (M/F) & $7(2 / 5)$ \\
Vocal polyp (M/F) & $7(2 / 5)$ \\
\hline
\end{tabular}

Values are presented as mean $\pm \mathrm{SD}$ or number.

$\mathrm{M}=$ male; $\mathrm{F}=$ female.

한 후 전체적으로 마사지를 실시하되, 과긴장이 관찰된 부분은 보 다 더 집중적으로 마사지를 실시하였다. 환자에게 "꽃 향기 맡듯이 가볍게 코로 숨을 들이 쉬고, 내쉴 때는 약 바른 상처에 바람을 불 듯이 길고 천천히 부드럽게 하세요”라고 주의를 준 후, 호기 시에만 한 손을 사용하여 후두마사지를 실시하였으며, 총 소요시간은 7-10 분 내외였다. 후두마사지 순서는 흥쇄유돌근과 설골상근 및 설골 하근, 설골과 갑상연골 사이 갑상연골막 앞쪽의 순서로 진행하였 다. 흥쇄유돌근은 쇄골에서 유양돌기방향으로 마사지 실시 후 다 시 쇄골쪽으로 양쪽 각각 실시하였으며, 설골 뒤편과 설골상근 및 하근은 엄지와 검지로 원을 그리듯 안에서 밖으로, 밖에서 안으로 마사지 하였다. 다음으로 갑상연골 대각(superior horn)주변을 엄 지를 이용하여 양쪽 각각 원을 그리듯 마사지 후 엄지와 검지로 다 시 양쪽을 동시에 마사지 하였다. 갑상설골 막 앞쪽은 먼저 엄지와 검지를 이용해 밖에서 안으로 마사지 후 갑상연골 대각(superior horn)을 아래로 살짝 누른 후 환자가 턱을 서서히 위쪽으로 들게 하 였다. 이후 엄지와 검지를 이용해 갑상연골을 아래 쪽으로 충분히 하강시켰다. 마지막으로, 엄지를 이용해 갑상연골을 각각 좌측과 우측으로 민 상태에서 심호흡하도록 하였다.

\section{반폐쇄성도운동}

반폐쇄운동은 인위적이지만 가장 효율성이 높은 반폐쇄성도부 터 가장 자연스러운 상태 순으로 연습을 실시하였으며(Choi, 2017; Titze, 2002a), 사용된 반폐쇄성도운동은 직경이 작은 저항이 매우 높은 빨대 발성, 저항이 비교적 적은 넓은 빨대를 이용한 발성, 양 순유성마찰음[ㅂ:], 입술트릴, 비강자음을 이용한 허밍발성 순으로 각각 5-10분씩 진행하였다.

반폐쇄성도운동 수행 시에 연구자는 반폐쇄성도운동의 모델링 을 제시하고 환자가 모방하도록 하였다. 수행과제는 음도상승과 하 강, 연장발성 두 가지의 형태로 gliding이나 scaling을 통해 음도상 승과 하강을 실시한 후 펄스 성구, 흥성구, 가성구에서 반폐쇄성도 운동으로 연장발성 하였다. 예를 들면, 입술 트릴로 gliding과 scaling으로 음도상승과 음도 하강을 반복적으로 실시 하고, 이후 흥성
구에서 입술 트릴로 음도변화가 없는 연장발성을 하였다. 이후 각각 가성구와 펄스성구에서 동일하게 입술 트릴로 연장발성을 실시하 였다. 이와 같은 방법으로 허밍과 양순파열음[ㅂ:], 빨대발성도 동일 하게 실시하였는데, 허밍 시에는 충분히 공명될 수 있도록 구강과 인두강 확장과 함께 원순모음/기/의 포즈를 유지하도록 하였으며, 양순마찰음[ㅂ:]은 '뱃고동 소리'를 내는 것과 유사한 것이라고 먼 저 설명하고, 대상자가 하인두의 팽창을 지각하고 유지하도록 하였 다. 특히, 반폐쇄성도운동에서는 환자들이 감각에 대한 지각을 할 수 있도록 연장발성의 후반부에 나타나는 상복근의 수축감과 허밍 이나 양순마찰음[ㅂ: ] 발성, 빨대 발성 시 나타나는 안면의 공명감 에 집중하도록 하였다. 이러한 감각에 대한 지각을 통해 환자는 더 정확하고 쉽게 반폐쇄성도운동 과제를 수행할 수 있었다.

\section{음향학적 분석}

음성치료 전후 소음이 통제된 조용한 검사실에서 환자의 음성을 녹음하였다. 환자로 하여금 마이크와 입과 약 $10 \mathrm{~cm}$ 의 거리를 두고 편안한 음도와 강도에서 모음//를 연장발성을 하도록 하였으며, 28 명의 환자로부터 총 56 개의 음성자료를 얻어내었다./F/연장 발성 중 안정구간 1 초를 선택하여 Kay PENTAX사에서 개발한 Multispeech 3.7의 Multi-Dimensional Voice Program (MDVP)를 이용 하여 기본주파수 관련 변수 Average Fundamental Frequency $\left(\mathrm{F}_{0}\right)$, Standard Deviation of $\mathrm{F}_{0}$ (STD), Jitter Percent (Jitter), Pitch Perturbation Quotient ( $\mathrm{PPQ})$, Fundamental Frequency Variation $\left(\mathrm{vF}_{0}\right)$ 와 음성강도 관련 변수 Shimmer Percent (Shimmer), Amplitude Perturbation Quotient (APQ), Peak to Peak Amplitude Variation (vAm), 진전 관련 변수 $\mathrm{F}_{0}$ Tremor Intensity Index (FTRI), Amplitude Tremor Intensity Index(ATRI), 잡음 관련 변수 Noise to Harmonic Ratio (NHR), Voice Turbulence Index (VTI), Soft Phonation Index (SPI), Sub-harmonic 관련 변수 Degree of Sub-Harmonic (DSH), Degree of Voiceless (DUV)를 분석하여 음향학적 차이 를 확인하였다.

\section{청지각적 평가}

본 연구자는 음성치료 전후//고음 연장발성을 듣고, GRBAS척 도로 청지각적 평가를 실시하였다. 청지각적 평가의 신뢰도 확인을 위해 이비인후과 음성장애 임상경험 5 년 이상인 1 급언어재활사 2 명이 수집된 무작위로 배치된 녹음자료를 듣고 각각 청지각적 평정 을 실시하였다. 검사-재검사 신뢰도를 검사하기 위하여 음성자료 중 무작위로 추출한 $20 \%$ 를 평가하였다. 연구자와 다른 임상가 간 의 'G', 'R', 'B', 'A', 'S'의 검사자 간의 신뢰도는 각각 $92 \%, 86 \%, 83 \%$, 
$80 \%, 82 \%$ 였으며, ' $\mathrm{G}$ ', 'R', 'B', 'A', 'S'의 검사-재검사 신뢰도는 검사 자 1 은 $97 \%, 93 \%, 94 \%, 88 \%, 90 \%$ 였고 검사자2는 $95 \%, 90 \%, 93 \%$, $86 \%, 88 \%$ 였다. 두 검사자 간 GRBAS점수가 일치하지 않는 경우는 두 검사자가 동시에 같이 듣고 최종적으로 동의한 점수를 최종 측 정치로 하였다.

\section{첫 회기 음성치료 후 음성치료 참여 여부}

과기능 음성장애 환자의 음성치료 참여도를 살펴보고자 음성치 료 첫 회기 후 대상자들의 음성치료 여부를 즉시 종결(immediately termination after 1st voice therapy), 음성치료 후 임상가 종결(termination after voice therapy), 수술 취소 후 음성치료, 환자의 치료 종결 요구(demand of voice therapy termination), 후두미세술 시행 (microsurgery)으로 분류하였다.

\section{통계분석}

수집한 자료를 통해 음성치료 전후의 음향학적 특성과 청지각적 차이를 알아보기 위해 SPSS (Statistics Package for the Social Science version 21.0)을 이용하여 과기능적 음성장애 집단별로 Wilcoxon's signed-ranks test를 실시하였으며 95\% 수준에서 유의성을 검증하였다.

\section{연구결과}

\section{음성치료 전후의 음향학적 검사결과 및 청지각적 측정치 비교}

$\mathrm{MDVP}$ 를 이용한 음성치료 전후 음향학적 검사는 Tables 2, 3과 같다. 기본주파수의 표준편차(STD)는 근긴장성발성장애(muscle tension dysphonia, MTD)집단은 치료 전 $8.913 \mathrm{~Hz}$, 치료 후 1.784 $\mathrm{Hz}$ 로 감소하였으며, 성대결절 집단은 $9.77 \mathrm{~Hz}$ 에서 $1.68 \mathrm{~Hz}$ 로 감소 하였고, 성대용종 집단은 $3.12 \mathrm{~Hz}$ 에서 $2.93 \mathrm{~Hz}$ 으로 감소하였다. 주파 수변동률(Jitter)은 MTD 집단이 치료 전 2.384\%에서 치료 후 $0.719 \%$ 로 성대결절 집단은 치료 전 $1.357 \%$ 에서 치료 후 $0.925 \%$ 로 성대용 종 집단은 $1.606 \%$ 에서 치료 후 $0.613 \%$ 로 감소하였다. 장단기 주파 수 변이에 해당하는 PPQ는 MTD 집단이 치료 전 $1.474 \%$ 에서 치료 후 $0.43 \%$ 로, 성대결절 집단이 치료 전 $0.816 \%$ 에서 치료 후 $0.525 \%$ 로, 성대용종 집단이 치료 전 $0.943 \%$ 에서 치료 후 $0.36 \%$ 로 감소하 였다. 강도변동률(shimmer)은 MTD 집단은 치료 전 $10.021 \%$ 에서 치료 후 5.931\%로, 성대결절 집단은 치료 전 $9.053 \%$ 에서 치료 후 $5.04 \%$ 로, 성대용종 집단은 치료 전 $7.55 \%$ 에서 치료 후 $4.339 \%$ 로 감 소하였다. $\mathrm{vF}_{\mathrm{o}}$ (기본주파수 변이)는 $\mathrm{MTD}$ 집단이 치료 전 $5.31 \%$ 에
Table 2. Comparison of acoustic measures before and after trial therapy in the muscle tension dysphonia group

\begin{tabular}{lccc}
\hline & Before & After & $Z$ \\
\hline STD & $8.913(13.137)$ & $1.784(1.347)$ & $-3.233^{* * *}$ \\
Jitter & $2.384(1.526)$ & $.719(.374)$ & $-3.233^{* * *}$ \\
PPO & $1.474(1.001)$ & $.430(.238)$ & $-3.296^{* * *}$ \\
vFo & $5.310(8.255)$ & $.913(.573)$ & $-3.233^{* * *}$ \\
Shimmer & $10.021(4.581)$ & $5.932(2.193)$ & $-2.919^{* *}$ \\
APO & $7.288(3.678)$ & $4.531(1.704)$ & $-2.856^{* *}$ \\
VAm & $15.830(8.614)$ & $9.517(3.595)$ & $-2.480^{*}$ \\
NHR & $.226(.107)$ & $.143(.026)$ & $-3.140^{* *}$ \\
VTI & $.079(.032)$ & $.057(.017)$ & $-2.544^{*}$ \\
SPI & $5.502(2.403)$ & $5.428(3.185)$ & -.534 \\
FTRI & $0.414(0.384)$ & $.184(.190)$ & $-2.062^{*}$ \\
ATRI & $5.792(6.739)$ & $2.075(2.132)$ & -1.600 \\
DSH & $5.641(8.481)$ & $1.283(2.580)$ & -1.859 \\
DUV & $14.219(25.228)$ & $.000(.000)$ & $-2.366^{*}$ \\
\hline
\end{tabular}

Values are presented as mean (SD).

$\mathrm{STD}=$ standard deviation of $\mathrm{F}_{0} ; \mathrm{PPO}=$ pitch perturbation quotient; $\mathrm{vF}_{0}=$ fundamental frequency variation; $\mathrm{APO}=$ amplitude perturbation quotient; $\mathrm{vAm}=$ peak to peak amplitude variation; NHR= noise to harmonic ratio; VTI=Voice Turbulence Index; $\mathrm{SPI}=$ Soft Phonation Index; FTRI = $\mathrm{F}_{0}$ Tremor Intensity Index; ATRI = Amplitude Tremor Intensity Index; DSH= degree of sub-harmonic; DUV= degree of voiceless. ${ }^{*} p<.05,{ }^{* *} p<.01,{ }^{* * *} p<.001$.

서 치료 후 $0.913 \%$ 로, 성대결절 집단이 치료 전 5.994\%에서 치료 후 $0.932 \%$ 로, 성대용종 집단이 치료 전 $1.717 \%$ 에서 치료 후 $0.854 \%$ 로 감소되었다. vAm (강도변이)는 MTD 집단이 치료 전 $15.83 \%$ 에서 치료 후 $9.517 \%$ 로, 성대결절 집단이 치료 전 $13.265 \%$ 에서 치료 후 $8.675 \%$ 로, 성대용종 집단이 치료 전 $12.314 \%$ 에서 치료 후 $11.161 \%$ 로 감소하였다. 비정상배음의 비율을 반영하여 음성의 전반적 잡음 을 설명하는 $\mathrm{NHR}$ (잡음대 소음비)은 MTD 집단이 치료 전 0.226 서 치료 후 0.143 로, 성대결절 집단이 치료 전 0.17 에서 치료 후 0.148 로, 성대용종 집단이 치료 전 0.168 에서 치료 후 0.138 로 감소되었 다. VTI (고주파 잡음대 소음비)는 MTD 집단이 치료 전 0.079에서 치료 후 0.057 로, 성대결절 집단이 치료 전 0.062 에서 치료 후 0.054 로, 성대용종 집단이 치료 전 0.070 에서 치료 후 0.05 로 감소되었다. SPI (저주파와 고주파의 배음구조)은 MTD 집단이 치료 전 5.5에 서 치료 후 5.4로, 성대결절 집단이 치료 전 8.1에서 치료 후 7.2 로 감 소되었으며, 성대용종 집단이 치료 전 6.0 에서 치료 후 6.5 로 증가하 였다. FTRI (기본 주파수 진전)은 MTD집단이 치료 전 $0.414 \%$ 에서 치료 후 $0.184 \%$ 로, 성대결절 집단이 치료 전 $0.346 \%$ 에서 치료 후 $1.55 \%$ 로, 성대용종 집단이 치료 전 $0.361 \%$ 에서 치료 후 $0.329 \%$ 로 감소되었다. ATRI (음성강도 진전)은 MTD 집단이 치료 전 5.792\% 에서 치료 후 $2.075 \%$ 로, 성대결절 집단이 치료 전 $6.504 \%$ 에서 치료 후 $2.307 \%$ 로, 성대용종 집단이 치료 전 $3.51 \%$ 에서 치료 후 $1.052 \%$ 
Table 3. Comparisons of MDVP acoustic measures before and after voice therapy in the vocal nodules and polyp groups

\begin{tabular}{|c|c|c|c|c|c|c|}
\hline & \multicolumn{3}{|c|}{ Nodules } & \multicolumn{3}{|c|}{ Polyp } \\
\hline & Before & After & $Z$ & Before & After & $Z$ \\
\hline STD & $9.767(20.352)$ & $1.676(0.695)$ & -1.859 & 3.115 (3.064) & $2.933(4.492)$ & -1.014 \\
\hline Jitter & $1.357(0.897)$ & $0.925(0.562)$ & -1.859 & 1.606 (1.496) & $0.613(0.234)$ & $-2.197^{*}$ \\
\hline PPO & $0.816(0.528)$ & $0.525(0.292)$ & -1.859 & 0.943 (0.909) & $0.360(0.151)$ & $-2.197^{*}$ \\
\hline $\mathrm{vF}_{0}$ & 5.994 (12.690) & $0.932(0.319)$ & -1.859 & $1.717(1.342)$ & 0.854 (0.369) & -1.859 \\
\hline Shimmer & $9.053(4.753)$ & 5.040 (2.204) & $-2.197^{*}$ & 7.550 (3.101) & 4.339 (1.730) & $-2.366^{*}$ \\
\hline APO & 6.616 (3.139) & $3.830(1.480)$ & $-2.366^{*}$ & $4.965(1.875)$ & $3.311(1.141)$ & $-2.366^{*}$ \\
\hline vAm & $13.265(4.730)$ & $8.675(4.643)$ & $-2.028^{*}$ & $12.314(4.622)$ & $11.161(4.211)$ & -.676 \\
\hline NHR & $0.170(0.044)$ & $0.148(0.022)$ & -1.363 & $0.168(0.050)$ & $0.138(0.019)$ & -1.572 \\
\hline VTI & $0.062(0.016)$ & $0.054(0.017)$ & -1.014 & $0.070(0.025)$ & $0.050(0.010)$ & -1.521 \\
\hline SPI & $8.103(3.450)$ & 7.259 (2.379) & -1.014 & 6.071 (3.608) & 6.526 (4.892) & -.507 \\
\hline FTRI & $0.346(0.233)$ & $0.155(0.206)$ & $-1.992^{*}$ & $0.361(0.352)$ & $0.329(0.276)$ & -.105 \\
\hline ATRI & 6.504 (2.729) & 2.307 (2.634) & $-2.366^{*}$ & $3.510(3.877)$ & $1.052(1.317)$ & -1.363 \\
\hline DSH & $4.593(4.903)$ & 2.192 (3.832) & -1.095 & 4.889 (8.855) & 0.000 & -1.342 \\
\hline DUV & 4.700 (9.082) & $0.000(0.000)$ & -1.342 & 0.866 (2.291) & 0.000 & -1.0 \\
\hline
\end{tabular}

Values are presented as mean (SD).

$\mathrm{MDVP}=$ Multi-Dimensional Voice Program; $\mathrm{STD}=$ standard deviation of $\mathrm{F}_{0} ; \mathrm{PPQ}=$ pitch perturbation quotient; $\mathrm{VF}=$ = fundamental frequency variation; $\mathrm{APQ}=\mathrm{amplitude} \mathrm{perturba-}$ tion quotient; $v A m=$ peak to peak amplitude variation; NHR=noise to harmonic ratio; VTI=Voice Turbulence Index; SPI = Soft Phonation Index; FTRI= $\mathrm{F}_{0}$ Tremor Intensity Index; ATRI = Amplitude Tremor Intensity Index; DSH = degree of sub-harmonic; DUV = degree of voiceless.

${ }^{*} p<.05,{ }^{* *} p<.01,{ }^{* * *} p<.001$.

Table 4. Comparison of FO measures before and after trial therapy

\begin{tabular}{lllc}
\hline & \multicolumn{1}{c}{ Before } & \multicolumn{1}{c}{ After } & $Z$ \\
\hline MTD & & & \\
Male $(\mathrm{N}=4)$ & $192.976(50.024)$ & $203.590(25.132$ & -.866 \\
Female $(\mathrm{N}=10)$ & $148.511(46.646)$ & $155.060(23.706)$ & -.365 \\
Nodules & & & \\
$\quad$ Male $(\mathrm{N}=2)$ & $179.417(22.105)$ & $198.083(25.355)$ & -.573 \\
Female $(\mathrm{N}=5)$ & $137.433(.682)$ & $132.688(.196)$ & -1.342 \\
Polyp & & & \\
Male (N=2) & $195.495(33.105)$ & $200.160(36.874)$ & -1.483 \\
Female (N=5) & $107.209(9.520)$ & $126.212(28.557$ & -1.342 \\
\hline
\end{tabular}

Values are presented as mean (SD).

$\mathrm{MTD}=$ muscle tension dysphonia.

${ }^{*} p<.05,{ }^{* *} p<.01,{ }^{* * *} p<.001$.
로 감소되었다. 전체 음성샘플에서 기본주파수가 측정되지 않는 non-hamonics이 나타나는 길이 비율을 나타내는 DUV (무발성 정 도)는 MTD 집단이 치료 전 $14.21 \%$ 에서 치료 후 $0 \%$ 로, 성대결절 집 단이 치료 전 $4.7 \%$ 에서 치료 후 $0 \%$ 로, 성대용종 집단이 치료 전 $0.866 \%$ 에서 치료 후 0 으로 감소되었다. DSH (이중음성 정도)는 MTD 집단이 치료 전 5.641에서 치료 후 1.283 로, 성대결절 집단이 치료 전 4.539 에서 치료 후 2.192 로, 성대용종 집단이 치료 전 4.889 에서 치료 후 0 으로 감소되었다. MTD집단은 음향학적 변수 중 STD, Jitter, PPQ, $\mathrm{vF}_{0}$, Shimmer, APQ, vAm, NHR, VTI, FTRI, ATRI, DUV에서 Nodule집단은 Shimmer, APQ, vAm, FTRI, ATRI 에서 Polyp집단은 Jitter, PPQ, Shimmer, APQ에서 유의한 차이를

Table 5. Comparisons of auditory-perceptual measures before and after trial therapy during /a/ sustained vowel phonation among hyperfunctional dysphonic groups

\begin{tabular}{|c|c|c|c|c|c|c|c|c|c|}
\hline & \multicolumn{3}{|c|}{ MTD } & \multicolumn{3}{|c|}{ Nodules } & \multicolumn{3}{|c|}{ Polyp } \\
\hline & Before & After & $Z$ & Before & After & $Z$ & Before & After & $Z$ \\
\hline G & $2.214(.699)$ & $1.071(.475)$ & $-2.859^{* *}$ & $1.571(.787)$ & $1.00(.577)$ & $-2.0^{*}$ & $1.857(.690)$ & $1.286(.756)$ & $-2.0^{*}$ \\
\hline $\mathrm{R}$ & $1.286(.914)$ & $.500(.650)$ & $-2.598^{* *}$ & $1.143(.690)$ & $.571(.535)$ & $-2.0^{*}$ & $.714(.756)$ & $.429(.535)$ & -1.414 \\
\hline B & $1.071(.829)$ & $.500(.650)$ & $-2.530^{*}$ & $.714(1.113)$ & $.429(.787)$ & -1.414 & $1.286(1.113)$ & $.857(.900)$ & -1.732 \\
\hline A & $.429(.756)$ & $.000(.000)$ & -1.857 & $.143(.378)$ & .000 & -1.0 & $.143(.378)$ & .000 & -1.0 \\
\hline S & $.429(.756)$ & $.143(.363)$ & -1.633 & $.143(.378)$ & .000 & -1.0 & $.286(.488)$ & .000 & -1.414 \\
\hline
\end{tabular}

Values are presented as mean (SD).

MTD = muscle tension dysphonia.

${ }^{*} p<.05,{ }^{* *} p<.01,{ }^{* * *} p<.001$. 
Table 6. Voice therapy adherence after 1 st voice therapy session

\begin{tabular}{lccccc}
\hline & Immediately & VT & Cancel and VT & Demand & Surgery \\
\hline MTD & $8(28.6)$ & $5(17.9)$ & - & $1(3.6)$ & - \\
Nodules & $1(3.6)$ & $3(10.7)$ & $1(3.6)$ & $2(7.1)$ & - \\
Polyp & - & - & $2(7.1)$ & $2(7.1)$ & $3(10.7)$ \\
Total & $9(32.1)$ & $8(28.6)$ & $3(10.7)$ & $5(17.9)$ & $3(10.7)$
\end{tabular}

Values are presented as number (\%).

Immediately=immediately termination after 1st voice therapy session; $\mathrm{VT}=$ termination after voice therapy; Cancel and VT=cancellation of surgery followed by voice therapy; Demand = demand for voice therapy termination.

Table 7. Average number of sessions until termination of voice therapy

\begin{tabular}{lccccc}
\hline & Immediately & VT & Cancel and VT & Demand & Surgery \\
\hline MTD & 1.0 & 2.6 & - & 2.0 & - \\
Nodules & 1.0 & 3.0 & 2.0 & 2.0 & - \\
Polyp & - & - & 3.0 & 1.5 & 1 \\
Total & 1.0 & 2.8 & 2.5 & 1.8 & 1 \\
\hline
\end{tabular}

Immediately= immediately termination after 1 st voice therapy session; $\mathrm{VT}=$ termination after voice therapy; Cancel and VT=cancellation of surgery followed by voice therapy; Demand = demand for voice therapy termination.

보였다 $(p<.05)$. 치료 전후 기본주파수 변화는 Table 4 와 같았으며, 치료 전후 유의미한 차이는 보이지 않았다 $(p>.05)$.

GRBAS를 이용하여 음성치료 전후 청지각적 평가를 비교한 결 과는 Table 5와 같다. MTD 집단은 ' $G$ ’ 척도는 치료 전 2.214에서 치 료 후 1.071 로, 'R' 척도는 치료 전 1.286 에서 치료 후 0.5 로, 'B' 척도 는 치료 전 1.071 에서 치료 후 0.5 로, 'A' 척도는 치료 전 0.429 에서 치료 후 0 으로, ' $\mathrm{S}$ ' 척도는 치료 전 0.429 에서 0.143 으로 감소하였다. 성대결절 집단은 ' $\mathrm{G}$ ' 척도는 치료 전 1.571 에서 치료 후 1.0 으로, 'R' 척도는 치료 전 1.143 에서 치료 후 0.571 로, 'B' 척도는 치료 전 0.714 에서 치료 후 0.429 로, 'A' 척도는 치료 전 0.143 에서 치료 후 0 으로, 'S' 척도는 치료 전 0.143 에서 치료 후 0 으로 감소하였다. 성대용종 집단은 ' $\mathrm{G}$ ' 척도는 치료 전 1.857 에서 치료 후 1.286 로, ' $\mathrm{R}$ ' 척도는 치료 전 0.714 에서 치료 후 0.429 로, ' $\mathrm{B}$ '척도는 치료 전 1.286 에서 치 료 후 0.857 로, 'A' 척도는 치료 전 0.143 에서 치료 후 0 으로, ' $\mathrm{S}$ ' 척도 는 치료 전 0.286 에서 치료 후 0 으로 감소하였다. MTD 집단은 $\mathrm{G}$, $\mathrm{R}, \mathrm{B}$ 에서 성대결절 집단은 $\mathrm{G}, \mathrm{R}$ 에서 성대용종 집단은 $\mathrm{G}$ 에서 유의 한 차이를 보였다 $(p<.05)$.

첫 회기 음성치료 이후 각 집단 대상자들의 음성치료 중단율을 추적한 결과는 Table 6과 같다. Figure 1에서 나타난 바와 같이 총 28 명 중 음성치료 첫 회기 실시 후 즉각적인 음성개선 효과로 음성 치료를 바로 종결한 경우는 9명(32.1\%), 음성치료 후음성치료를 지 속해서 받은 경우 8 명(28.6\%), 수술을 취소하고 음성치료를 받은 경

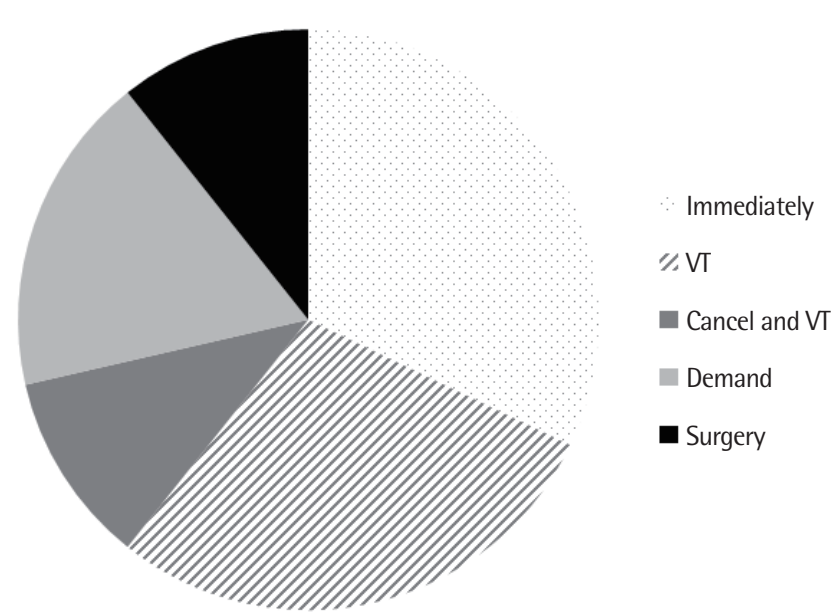

Figure 1. Voice therapy termination and adherence rate. Immediately=immediately termination after 1st voice therapy session; VT= termination after voice therapy; Cancel and VT= cancellation of surgery followed by voice therapy; Demand=demand for voice therapy termination.

우 3명(10.7\%), 17.9\%에 해당하는 5명도 첫 회기 음성치료 후 음성 치료를 지속적으로 받았으며 음성개선으로 인해 대상자의 요구에 의해 중도 종결하였다. 따라서, 첫 회기 음성 치료 후 지속적으로 음 성치료를 받은 경우가 가장 많았으며, 3 명(10.7\%)은 성대용종 환자 로서 예정대로 후두미세술을 받았다.

첫 번째 음성치료 이후 종결까지 실시한 음성치료 세션 수는 Table 7과 같다. Table 7에 나타난 바와 같이 연구 대상자 중 MTD 진 단 받은 14 명 중 8 명은 음성치료 1 회 실시 후 즉각적인 음성개선으 로, 5 명은 음성치료 2.6 회 실시 후 치료사에 의해 종결되었으며, 2 명 은 음성치료 2회 실시 후 치료기간 중 음성에 대한 만족을 나타내 어 환자의 요구에 의해 종결하였다. 성대결절로 진단 받은 대상자 7 명 중 1 명은 1 회음성치료 실시 후 1 회 더 음성치료를 받았으며, 3 명 은 음성치료 3회 실시 후, 2 명은 예정된 후두미세술을 취소하고 2 회 음성치료 더 받았고, 그 후 치료사에 의해 종결되었다. 또한 성대 결절 환자 중 2 명은 음성치료 2 회 실시 후 치료기간 중 음성에 대한 만족을 나타내어 환자의 요구에 의해 종결하였다. 성대용종으로 진단 받은 대상자 7명 중 2명은 첫 번째 음성 치료 이후 예정된 후 두미세술 취소하고 음성 치료를 받기 원하여 3회 음성치료를 받았 고, 치료사에 의해 종결되었다. 또한, 성대용종 환자 중 2 명은 음성 치료 1.5 회 실시 후음성치료 기간 중 음성에 대한 만족을 나타내어 환자의 의해 종결되었다. 한편, 성대용종 환자 나머지 3 명은 음성치 료로 인한 만족할만한 음성개선이 나타나지 않아 예정대로 후두미 세술을 받았다. 


\section{논의 및 결론}

음성장애의 치료법은 후두미세술과 같은 수술적 치료, 약물치 료, 음성치료가 있으며 이 가운데 음성치료는 가장 핵심적인 치료 방법으로 간접치료와 직접치료로 구분 할 수 있다. 음성치료에서 있어 간접치료는 후두의 구조와 기능을 환자에게 인식 시키고 음 성위생프로그램을 통해 환자의 잘못된 음성산출 습관을 수정하도 록 하는 것이라면 직접치료는 음성효율을 증가시키고 음질을 개선 시켜 주는 특정 방법에 초점을 맞춤으로써 성대 건강에 나쁜 영향 을 미치는 음성산출 습관을 수정하고 후두의 병리적 상태를 개선 시키는 것을 목표로 한다. 직접적인 음성치료법에는 하품-한숨기 법, 후두마사지, 노래조로 말하기 등의 음성촉진기법이 있으며, 공 명 음성치료기법, 성대기능 훈련, 엑센트 기법, 반폐쇄성도운동기법 (Titze, 2006)과 같이 호흡, 발성, 공명의 협응에 초점을 맞춘 총체적 음성치료(holistic voice therapy) 등이 음성장애 환자의 주된 직접 적인 음성치료 방법으로 사용 되어 왔다(Ferrand, 2011).

본 연구는 반폐쇄성도운동기법 중 입술 트릴, 허밍, 양순마찰음, 빨대 발성을 사용하여 과기능성 음성장애 환자의 즉각적인 치료효 과를 살펴보았고 이후의 음성치료 참여와 중단여부를 추적 조사 하였다. 본 연구에 사용된 SOVTE 중 입술 트릴은 연장발성 동안 두 입술과 성대에서 진동이 일어나며, 연장된 허밍과 양순유성마 찰음을 이용한 발성은 비음 /ㅁ/, / ㄴ/이나/비과 같이 목표 자음을 위해 성도를 폐쇄하는 하는 동안 이루어진다. 빨대발성은 입술 사 이에 빨대를 물고 소리를 내는 방법으로 발성 동안 저항을 제공한 다. 성도의 길이를 인위적으로 증가시키면 성도의 음향관성(acoustic inertance)을 증가시킬 수 있다. 빨대의 길이나 너비에 따라 공기 흐름에 대한 저항이 달라질 수 있는데 빨대 직경이 좁을수록 더 큰 저항을 주고, 넓을수록 더 낮은 저항을 준다(Choi, 2017). 빨대를 이용한 발성은 발성 동안 생성되는 구강내압을 증가시켜 성문과 대 등한 임피던스를 제공한다(Titze, 2002a, 2002b).

허밍과 같이 비음을 사용하는 SOVTE는 성도의 앞부분인 입술 부분을 막아 여과기인 성도로부터 음원인 성대에 입 뒤쪽의 압력 (back pressure) 즉, 구강압을 증가시켜 성대가 약간 외전된 상태를 만듦으로써 성대 부딪힘을 최소화할 수 있다. 또한, 발성은 성대가 진동할 때 공기역학적 에너지가 음향학적 에너지로 변환되고 소리 에너지는 성도를 따라 길게 전파된다. 이때, 성도의 일부분을 막으 면 그 에너지가 막은 부위에 닿아 감각적 피드백을 느끼게 되는데, 허밍과 같이 입술을 막으면 음향학적 에너지가 입술과 얼굴 안면부 위에 전달되어 공명의 감각을 느끼도록 도와준다(Choi, 2017; Titze, 2006). 양순마찰음 [ㅂ:]발성은 볼을 부풀려 구강에 공기를 가
득 채우고 볼이 꺼지지 않게 하면서 입술을 좁히고 불게 되는데 이 때 성대는 동시에 진동하면서 소리를 내게 된다. 이러한 SOVTE는 구강을 통과하는 기류를 증가시키고 허밍과 같이 성도의 앞부분을 좁혀 입 뒤쪽 압력인 구강압을 증가시켜 허밍과 동일한 효과를 가 져온다.

본 연구에서는 사용된 SOVTE 방법들은 구강에서의 좁힘으로 인해 구강에서 큰 음향압력을 가지게 하여 환자들에게 더 많은 공 명 감각 피드백을 줄 수 있었으며, 구강압을 증가시켜 성문상압과 성문하압의 차이를 줄여 성대가 부드럽게 접촉하여 진동할 수 있 도록 유도하였다.

본 연구에서 후두마사지와 SOVTE 음성치료 전과 후의 음향학 적 검사결과 비교 시, MTD 집단은 음도의 주기성을 나타내는 Jitter, $\mathrm{PPQ}$ 와 강도의 주기성을 나타내는 Shimmer, APQ, 음도의 변 이를 나타내는 $\mathrm{vF} 0$ 와 강도의 변이를 나타내는 vAm와 발화노력에 의해 병리적인 수준으로 증가할 수 있는 음도와 강도의 진전변수인 FTRI와 ATRI, 잡음관련 변수로 비정상배음의 비율을 반영하여 음성의 전반적 잡음을 설명하는 NHR과 성대 폐쇄의 불완전성을 반영하는 VTI와 기본주파수가 측정되지 않는 비율을 측정해 음성 끊김 없이 유지하는 능력을 나타내는 DUV가 유의미하게 감소하 였다. 성대결절 집단은 Shimmer, APQ, vAm, FTRI, ATRI가 성대 용종 집단은 Jitter, $\mathrm{PPQ}$, Shimmer, $\mathrm{APQ}$ 에서 유의미한 감소를 나 타내었다. 기본주파수는 세 집단 모두에서 유의미한 변화는 없었 으나, MTD 집단에서 $\mathrm{F}_{0}$ 의 표준편차로서 음성의 비정상을 나타내 는 STD가 유의미한 감소를 보였다.

청지각적 중증도가 증가할수록 Jitter, Shimmer, NHR는 증가하 고, 청지각적 중증도에 따라 이러한 변수 간의 차이를 보이기 때문 에 변동률 분석은 음성장애 환자의 음질을 판단하는데 대표적인 음향지표는 F0, Jitter, Shimmer, NHR (Wolfe, Fitch, \& Cornell, 1995)로, 그 중 Jitter와 Shimmer는 성대 안정성을 설명하는 파라미 터로 병적 음성을 구분하는 음향변수로서 그 타당도가 높고(Fex, Fex, Shiromoto, \& Hirano, 1994; Kong et al., 2007), PPQ와 APQ 역시 성대 진동의 규칙성을 나타내는 변수로 음성치료 전과 후의 결과를 양적으로 나타내는데 유용하다(Ahn, Lee, Kang, \& Lee, 1995; Hirano et al., 1988). 또한, 병리적 음성에서 후두기능은 강도 의 분포를 통해 반영될 수 있는데(Klingholz \& Martin, 1989; Kwon \&Wang, 2008), Hong, Yang과 Kim (2002)은 병적 음성에서 발화노 력의 증가에 따라 후두근의 긴장이 증가할 수 있으며 이러한 과긴 장이 내전 시 성대접촉률의 불안정함과 불완전함을 보상하는 것이 아니라 오히려 증가시킬 수 있어 발화노력이 강도의 변이를 나타내 는 vAm에 영향을 줄 수 있다고 보고했으며, Lee 등(2013)의 연구에 
서는 강도 진전변수인 ARTI가 발화노력으로 인해 병리적인 수준 으로 증가될 수 있다고 하였다.

청지각적 음성평가는 임상에서 음성장애의 중등도를 평가하는 정석으로(Kreiman, Gerratt, Kempster, Erma, \& Berke, 1993; Ma \& Yiu, 2006; Yu, Choi, Choi, \& Lee, 2017), 매우 복잡한 음향학적 성질은 가진 음질과 유동성 평가에 음향분석기기보다 임상적으로 더 우수한 도구이다(Sohn, 2008).

GRBAS 척도를 사용한 본 연구에서 음성치료 전과 후의 청지각 적 평가비교 시, 치료 전에 비해 치료 후 세 집단 모두에서 전반적인 중증도 $(\mathrm{G})$ 가 유의하게 감소하였으며, MTD 집단은 조조성(R)과 기 식성(B), 성대결절 집단은 조조성(R)에서도 유의한 청지각적인 음 성의 개선이 나타났다.

음성치료 후 음향학적 검사와 청지각적 평가에서 나타난 이러한 변화는 후두마사지와 SOVTE가 과긴장된 성도와 후두 내외근 이 완시키고, 성대에 부담을 주지 않는 경제지향적인 방법으로 성대접 촉을 강화하여 발화노력이 감소되고 성대의 진동이 규칙적이고 안 정화되었음을 의미하는 것이다.

Dargin, DeLaunay와 Searl (2016)는 혀 트릴과 입술 트릴, 튜브 발성과 같은 SOVTE 수행 시 성대의 진폭(amplitude)과 점막파동 (mucosal wave)이 증가하고 후두의 위치는 하강하며, 하인두와 성 문 전후의 압축이 이완됨을 보고했다. Guzman 등(2013)의 연구에 서도 튜브나 빨대를 이용한 발성 시 하인두가 넓어지고 후두가 낮 아지는 것이 컴퓨터 단층촬영(computed tomography, CT)을 통해 나타났다. 혀 트릴 수행 시간에 따른 성대변화를 알아보기 위해 Menezes 등(2011)은 성대결절로 진단받은 여성들을 대상으로 각 각 $1,3,5,7$ 분간 혀 트릴을 수행하도록 하였으며, 5 분 수행 시 청지 각적으로 전반적인 음질의 개선과 조조성 $(\mathrm{R})$, 기식성(B)이 감소되 고, 7 분 수행 시에는 오히려 긴장감 증가와 같은 부정적 반응이 나 타남을 보고하기도 했다. Ogawa 등(2014)은 MTD 환자를 대상으 로 허밍 시 청지각적인 조조성(R)과 음향학적인 섭동 매개변수의 감소를 보고하였으며, 이를 통해 허밍이 성대접촉의 불규칙성을 개 선시키고 성대진동의 규칙성을 조절하며, 성문접촉을 증가시키는 데 즉각적인 효과가 있음을 보고했다. 이외에도 Ogawa 등(2013)은 연성후두경을 통해 허밍이 MTD 환자의 성문상부 압축을 즉각적 으로 완화하는 것을 확인하였으며, 양성 성대점막질환자를 대상으 로 한 Vlot 등(2017)의 연구에서는 허밍 시 EGG 변동률 매개변수 의 변화가 나타났으며, 허밍이 성대진동을 안정화시켜 음질의 향상 을 가져오고 양성 성대점막질환자의 과도하거나 부적절한 긴장과 같은 기능적인 문제 해결에 도움이 될 수 있다고 보고했다. 경련성 발성장애 환자를 대상으로 Lax vox를 사용한 Lim, Choi, Kim과
Choi (2016) 연구에서는 VHI와 전반적인 음질(G), 노력성(S)이 감 소하고 최대연장발성(MPT)이 증가하였고, 기본 주파수의 표준편 차 감소를 통해 경련성 발성장애 환자의 떨림이 개선되었음을 보고 하였다. 이러한 선행연구의 결과들은 본 연구에서 사용한 SOVTE 의 종류와 적용방법과 일치하진 않으나, 성도의 수축을 기본으로 하는 SOVTE의 원리가 같다는 점에서 본 연구와 그 결과가 일치한 다고볼수있다.

본 연구에서 사용한 후두마사지법은 흥쇄유돌근을 집중적으로 실시하고 후두상부, 설골, 후두순으로 시행하는 LMT와 설골을 집 중적으로 실시하며 설골, 갑상설골근, 후두, 상설골근 순으로 시행 하는 MCT를 조합한 방법으로 전체적으로 마사지하되 촉진 시 과 긴장이 나타나는 부분을 집중적으로 마사지한다는 점과 통증을 4 점 척도로 확인한다는 점에서 Seo, Lee, Lee와 Jung (2011)의 LMGLMCT의 후두마사지와 유사하고, 마사지를 하는 순서와 부위가 고정되어 있는 MCT나 LMT와는 차이를 보이지만, 음성오남용에 서 기인하는 기능적 발성장애의 음성개선에 효과적이었다는 점에 서 선행연구의 결과들과 일치한다고 볼 수 있다(Aronson, 1990; Lee \& Son, 2005; Lieberman, 1998; Roy \& Leeper, 1993; Roy, Ford, \& Bless, 1996; Roy et al., 1997; Roy \& Ferguson, 2001; Van Lierde, De Ley, Clement, De Bodt, \& Van Cauwenberge, 2004).

첫 회기 음성치료 이후 대상자들 중 일부는 발성기관의 과긴장 이 이완되고 청지각적인 음성의 개선이 나타났으나, 재원 시 다시 청지각적 음질과 음향학적 파라미터에서 병리적인 문제가 나타나 는 경우도 있었다. 이는 음성의 오남용으로 인해 형성된 혹은 성대 의 병변으로 인한 음성문제를 보상하기 위해 형성된 발성습관이나 발화노력으로 인한 과긴장이 일회성의 시도치료만으로는 개선되 기 어려운 문제임을 의미하는 것이며, 이후 음성치료 세션에서 잘 못된 음성행동의 수정과 더불어 발성기관 이완, 호흡훈련과 같은 체계적인 이완훈련과 함께 음성오남용 외에 후두근긴장의 또 다른 원인으로 작용할 수 있는 신체의 자세와 움직임에 대한 중재의 필 요성을 시사하는 것이다.

최근 연구에 의하면 $38 \%$ 의 음성장애 환자가 의사의 음성치료 권 고를 듣지 않았으며(Portone, Johns, \& Hapner, 2008), 이 중에서 $47 \%$ 는 초기의 음성언어치료사의 평가 후 음성치료를 받으러 오지 않은 것으로 보고되었다. Hapner, Portone-Maira와 Johns (2009) 의 음성치료 중단에 영향을 미치는 요인에 대한 연구에서도 음성 치료 중단은 성별, 연령, 음성장애지수, CAPE-V와 같은 청지각적 평정, 혹은 진단명에 따라 별다른 차이를 보이지 않았다. 최근 Van Leer와 Conner (2010)의 연구에서는 음성치료 참여나 음성치료 지 속 여부에 환자의 치료에 대한 관심이나 동기나 신념이 매우 중요하 
다고 하였다. 본 연구에서 첫 회기 음성치료 이후 28 명의 대상자 중 5 명은 치료사의 종결판단 여부와 관련 없이 중도종결을 요구하여 치료를 중단했다. 하지만, 대상자들의 중단 요구가 음성치료를 통 해 변화된 자신의 음성에 대한 만족에 의한 것이었기 때문에 이 또 한 음성치료의 성공적인 결과라고 여길 수 있겠다.

본 연구는 후두마사지와 SOVTE로 구성하여 실시한 음성치료 가 음향학적, 청지각적 관점에서 과기능적 음성문제를 개선 시키 고, 음성평가 이후 음성치료의 참여와 중단에도 긍정적인 영향을 미칠 수 있다는 유용성에 관한 연구로 아직 시도적이지만 국내에 많이 알려지지 않은 SOVTE에 관한 근거기반중재(evidence-based practice)연구라는 점에서 연구의 의의가 있겠다.

후속 연구에서는 과대기능적 음성장애군을 대상으로 한 본 연 구와 달리, 과소기능적 음성장애군이나 기질적 음성장애, 신경학 적 음성장애등과 같이 다양한 음성장애질환군에서 더 많은 음성 장애 환자를 연구대상으로 한 근거기반연구가 필요하겠으며, 다른 종류의 반폐쇄성도운동으로 실시한 음성치료 결과에 대한 비교연 구도 이루어져야 할 것이다. 또한, 환자 관점에서의 문제 외에 음성 치료 참여에 영향을 줄 수 있는 다른 요인들을 조사함으로써 음성 치료의 중단이나 거부를 낮추고 음성치료의 지속성을 도모하는 노 력이 필요할 것이다.

\section{REFERENCES}

Ahn, C. M., Lee, J. H., Kang, H. K., \& Lee, Y. B. (1995). Significance of acoustic parameter (RAP, PPQ, APQ) in hoarseness. Journal of the Korean Society of Phoniatrics and Logotedics, 6, 22-26.

Ahn, C. M., Shin, I. S., \& Shin, J. E. (2016). The study of satisfaction of voice therapy in patients with voice disorders. Journal of the Korean Society of Laryngology Phoniatrics and Logopedics, 27, 35-39.

Aronson, A. E. (1990). Clinical voice disorders: an interdisciplinary approach. New York, NY: Thieme.

Berry, D. A., Verdolini, K., Montequin, D. W., Hess, M. M., Chan, R. W., \& Titze, I. R. (2001). A quantitative output-cost ratio in voice production. Journal of Speech, Language, and Hearing Research, 44, 29-37.

Boone, D. R., McFarlane, S. C., \& Von Berg, S. L. (2007). The voice and voice therapy (7th ed.). Seoul: SigmaPress.

Choi, S. H. (2013). Speech-language pathologists' voice assessment and voice therapy practices: a survey for standard clinical guideline and evidencebased practice. Communication Sciences \& Disorders, 18, 473-485.

Choi, S. H. (2017). Semi-occluded vocal tract exercise accent method, straw phonation, Lax Vox. Journal of the Korean Association for Voice of Performing Arts, 4, 11-19.

Dargin, T. C., DeLaunay, A., \& Searl, J. (2016). Semioccluded vocal tract exercises: changes in laryngeal and pharyngeal activity during stroboscopy. Journal of Voice, 30, 377.e1-377.e9.

Fadel, C. B. X., Dassie-Leite, A. P., Santos, R. S., Santos Junior, C. G. D., Dias, C. A. S., \& Sartori, D. J. (2016). Immediate effects of the semi-occluded vocal tract exercise with Lax Vox tube in singers. CoDAS, 28, 618-624.

Ferrand, C. T. (2011). Voice disorders: scope of theory and practice. Boston, MA: Pearson Education.

Fex, B., Fex, S., Shiromoto, O., \& Hirano, M. (1994). Acoustic analysis of functional dysphonia: before and after voice therapy (accent method). Journal of Voice, 8, 163-167.

Guzman, M., Castro, C., Testart, A., Muñoz, D., \& Gerhard, J. (2013). Laryngeal and pharyngeal activity during semioccluded vocal tract postures in subjects diagnosed with hyperfunctional dysphonia. Journal of Voice, 27, 709-716.

Guzman, M., Laukkanen, A. M., Krupa, P., Horáček, J., Švec, J. G., \& Geneid, A. (2013). Vocal tract and glottal function during and after vocal exercising with resonance tube and straw. Journal of Voice, 27, 523.e19-523.e34.

Hapner, E., Portone-Maira, C., \& Johns, M. M. (2009). A study of voice therapy dropout. Journal of Voice, 23, 337-340.

Hirano, M., Hibi, S., Yoshida, T., Hirade, Y., Kasuya, H., \& Kikuchi, Y. (1988). Acoustic analysis of pathological voice: some results of clinical application. Acta Oto-laryngologica, 105, 432-438.

Hong, K. H., Yang, Y. S., \& Kim, H. G. (2002). The effect of noise on the normal and pathological voice. Speech Sciences, 9, 27-38.

Klingholz, F., \& Martin, F. (1989). Distribution of the amplitude in the pathologic voice signal. Folia Phoniatrica et Logopaedica, 41, 23-29.

Kong, I. S., Cho, Y. J., Lee, M. H., Kim, J. S., Yang, Y. S., \& Hong, K. H. (2007). Comparative study on acoustic characteristics of vocal fold paralysis and benign mucosal disorders of vocal fold. Journal of the Korean Society of Phoniatrics and Logotedics, 18, 122-128.

Kreiman, J., Gerratt, B. R., Kempster, G. B., Erman, A., \& Berke, G. S. (1993). Perceptual evaluation of voice quality: review, tutorial, and a framework for future research. Journal of Speech, Language, and Hearing Research, 36, $21-40$.

Kwon, S. B., \& Wang, S. G. (2008). A study of acoustic features of voice of benign laryngeal disease patients. Journal of Special Education \& Rehabilitation Science, 47, 85-100. 
Laukkanen, A. M. (1992). Voiced bilabial fricative /B:/ as a vocal exercise: an electroglottographic and acoustic investigation. Scandinavian Journal of Logopedics and Phoniatrics, 17, 181-189.

Laukkanen, A. M., Lindholm, P., Vilkman, E., Haataja, K., \& Alku, P. (1996). A physiological and acoustic study on voiced bilabial fricative / $\beta$ :/ as a vocal exercise. Journal of Voice, 10, 67-77.

Lee, E. K., \& Son, Y. I. (2005). Muscle tension dysphonia in children: voice characteristics and outcome of voice therapy. International Journal of Pediatric Otorhinolaryngology, 69, 911-917.

Lee, J. S., Kim, J. P., Park, J. J., Kwon, O. J., \& Woo, S, H. (2013). Study for acoustic features of benign laryngeal disease. Journal of Korean Society of Laryngology, Phoniatrics and Logopedics, 24, 47-50.

Lieberman, J. (1998). Principles and techniques of manual therapy: application in the management of dysphonia. In T. Harris et al. (Eds.), The voice clinical handbook (pp. 91-138). London: Whurr.

Lim, H. J., Choi, S. H., Kim, J. K., \& Choi, C. H. (2016). Effects of Lax Vox voice therapy in a patient with spasmodic dysphonia: a case report. Phonetics and Speech Sciences, 8, 57-63.

Ma, E. P. M., \& Yiu, E. M. L. (2006). Multiparametric evaluation of dysphonic severity. Journal of Voice, 20, 380-390.

Mathieson, L., Hirani, S. P., Epstein, R., Baken, R. J., Wood, G., \& Rubin, J. S. (2009). Laryngeal manual therapy: a preliminary study to examine its treatment effects in the management of muscle tension dysphonia. Journal of Voice, 23, 353-366.

Menezes, M. H., Ubrig-Zancanella, M. T., Cunha, M. G. B., Cordeiro, G. F., Nemr, K., \& Tsuji, D. H. (2011). The relationship between tongue trill performance duration and vocal changes in dysphonic women. Journal of Voice, 25, e167-e175.

Ogawa, M., Hosokawa, K., Yoshida, M., Iwahashi, T., Hashimoto, M., \& Inohara, H. (2014). Immediate effects of humming on computed electroglottographic parameters in patients with muscle tension dysphonia. Journal of Voice, 28, 733-741.

Ogawa, M., Hosokawa, K., Yoshida, M., Yoshii, T., Shiromoto, O., \& Inohara, H. (2013). Immediate effectiveness of humming on the supraglottic compression in subjects with muscle tension dysphonia. Folia Phoniatrica et Logopaedica, 65, 123-128.

Portone, C., Johns, M. M., \& Hapner, E. R. (2008). A review of patient adherence to the recommendation for voice therapy. Journal of Voice, 22, 192196.

Radolf, V., Laukkanen, A. M., Horáček, J., \& Liu, D. (2014). Air-pressure, vo- cal fold vibration and acoustic characteristics of phonation during vocal exercising. Part 1: Measurement in vivo. Engineering Mechanics, 21, 53-59.

Roy, N. (2008). Assessment and treatment of musculoskeletal tension in hyperfunctional voice disorders. International Journal of Speech-Language Pathology, 10, 195-209.

Roy, N., \& Ferguson, N. A. (2001). Formant frequency changes following manual circumlaryngeal therapy for functional dysphonia: evidence of laryngeal lowering? Journal of Medical Speech Language Pathology, 9, 169176.

Roy, N., \& Leeper, H. A. (1993). Effects of the manual laryngeal musculoskeletal tension reduction technique as a treatment for functional voice disorders: perceptual and acoustic measures. Journal of Voice, 7, 242-249.

Roy, N., Bless, D. M., Heisey, D., \& Ford, C. N. (1997). Manual circumlaryngeal therapy for functional dysphonia: an evaluation of short-and longterm treatment outcomes. Journal of Voice, 11, 321-331.

Roy, N., Ford, C. N., \& Bless, D. M. (1996). Muscle tension dysphonia and spasmodic dysphonia: the role of manual laryngeal tension reduction in diagnosis and management. Annals of Otology, Rhinology \& Laryngology, 105, 851-856.

Seo, I. H., Lee, O. B., Lee, S. J., \& Chung, P. S. (2011). Effects of motor learning guided laryngeal motor control therapy for muscle misuse dysphonia. Phonetics and Speech Sciences, 3, 133-140.

Sohn, J. H. (2008). GRBAS and voice handicap index. Journal of the Korean Society of Phoniatrics and Logotedics, 19, 89-95.

Titze, I. R. (2002a). How to use the flow resistant straws. Journal of Singing, $58,429-430$

Titze, I. R. (2002b). Raising lung pressure and pitch in vocal warm-ups: the use of flow-resistant straws. Journal of Singing, 58, 329-338.

Titze, I. R. (2006). Voice training and therapy with a semi-occluded vocal tract: rationale and scientific underpinnings. Journal of Speech, Language, and Hearing Research, 49, 448-459.

Van Leer, E., \& Connor, N. P. (2010). Patient perceptions of voice therapy adherence. Journal of Voice, 24, 458-469.

Van Lierde, K. M., De Ley, S., Clement, G., De Bodt, M., \& Van Cauwenberge, P. (2004). Outcome of laryngeal manual therapy in four Dutch adults with persistent moderate-to-severe vocal hyperfunction: a pilot study. Journal of Voice, 18, 467-474.

Vlot, C., Ogawa, M., Hosokawa, K., Iwahashi, T., Kato, C., \& Inohara, H. (2017). Investigation of the immediate effects of humming on vocal fold vibration irregularity using electroglottography and high-speed laryngoscopy in pa- 
tients with organic voice disorders. Journal of Voice, 31, 48-56.

Wolfe, V., Fitch, J., \& Cornell, R. (1995). Acoustic prediction of severity in commonly occurring voice problems. Journal of Speech, Language, and Hearing Research, 38, 273-279.
Yu, M., Choi, S. H., Choi, C. H., \& Lee, K. (2017). Usefulness of cepstral acoustic index for estimating objective dysphonia severity. Communication Sciences \& Disorders, 22, 587-596. 


\section{국문초록}

\section{후두마사지와 반폐쇄성도훈련이 과기능적 음성장애 환자의 음성개선에 미치는 효과 김지성 ${ }^{1,2} \cdot$ 이동욱 ${ }^{3}$ 최철희 ${ }^{4} \cdot$ 최성희 ${ }^{4}$ \\ ${ }^{1}$ 대구가톨릭대학교 보건과학대학원, ${ }^{2}$ 충북대학교병원 이비인후과, ${ }^{3}$ 충북대학교 의과대학 이비인후과, ${ }^{4}{ }^{ }$구가톨ㄹ릭대학교 언어청각치료학과}

배경 및 목적: 높은 후두 위치, 인두 협착, 후두와 목 주변의 근긴장, 상후두의 과도한 수축이나 성대내전은 과기능 음성장애의 일반적 인 특징이다. 본 연구는 후두마시지와 반폐쇄성도법으로 구성한 음성치료프로그램 시행 후 즉각적인 음성 개선 변화를 살펴보고 이후 음성치료 참여에 미치는 영향을 살펴보고자 한다. 방법: 근긴장성발성장애나 성대결절, 성대용종으로 진단 받은 성인 28 명을 대상으로 후두마사지와 반폐쇄성도운동(입술 트릴, 허밍, 양순마찰음 [ㅂ: 발성, 빨대 발성)으로 구성된 음성치료를 실시하였다. 음성치료의 즉각 적인 효과를 살펴보기 위해 1 회 음성치료 전후 음향학적 검사와 청지각적 평가를 실시하였으며, 이후 음성치료 참여도를 측정하였다. 결과: 음성치료 후 음향학적 검사에서 STD, Jitter, Shimmer, NHR, vAm, vFo, ATRI, FTRI, PPQ, APQ, DSH, VTI, DUV가, 청지각적 평가에서는 'G', 'R', ‘B'에서 유의한 개선이 있었으며, 환자 대부분이 음성치료에 지속적으로 참여하였다. 논의 및 결론: 후두마사지와 반폐쇄성도기법으로 구성한 음성치료프로그램은 과기능적 음성장애를 보이는 환자의 음성 개선에 즉각적인 효과가 있었으며, 이후 음성치료에 긍정적인 영향을 미칠 수 있었다.

핵심어: 후두마사지, 반폐쇄성도훈련, 과기능 음성장애, 음성치료 참여

이 연구는 대구가톨릭대학교 교내연구비 지원을 받아 수행되었음.

\section{참고문헌}

공일승, 조영주, 이명희, 김종승, 양윤수, 홍기환(2007). 성대마비와 양성 성대점막질환의 음향학적 특성비교. 대한음성언어의학회지, 18, 122-128. 권순복, 왕수건(2008). 양성후두질환 환자의 음성에 대한 음향학적 특징에 관한 연구. 특수교육재활과학연구, 47,85-100.

서인효, 이옥분, 이상준, 정필상(2011). 운동학습이론에 기초한 발성운동조절법이 근오용성 발성장애의 음성에 미치는 효과. 말소리와 음성과학, 3 , $133-140$.

손진호(2008). GRBAS 음성평가와음성장애지수. 대한음성언어의학회지, 19, 89-95.

안철민, 신익서, 신정은(2016). 음성장애환자의 음성치료 후 만족도. 대한후두음성언어의학회지, 27,35-39.

안철민, 이종혁, 강현국, 이용배(1995). 애성환자에서 음향지표인 RAP, PPQ 및 $\mathrm{APQ}$ 의 유용성. 대한음성언어의학회지, 6, 22-26.

유미옥, 최성희, 최철희, 이경재(2017). 객관적인 음성장애 중증도 측정을 위한 캡스트럼 음향 지표의 유용성. 언어청각장애연구, 22, 587-596.

이재석, 김진평, 박정제, 권오진, 우승훈(2013). 양성 성대 점막 질환의 음향학적 특성에 관한 연구. 대한후두음성언어의학회지, 24, 47-50.

임혜진, 최성희, 김정규, 최철희(2016). 연축성 발성장애 환자의 Lax Vox 음성치료 효과. 말소리와 음성과학, 8, 57-63.

최성희(2013). 음성언어재활사의 음성평가와음성치료의 임상실제: 표준 임상지침과 증거기반중재를 위한 설문조사. 언어청각장애연구, 18, 473-485.

최성희(2017). 공연예술가를 위한 반폐쇄성도훈련: 악센트기법, 빨대 발성, Lax Vox. 한국공연예술발성연구회지, 4, 11-19.

홍기환, 양윤수, 김현기(2002). 소음환경이 정상 및 병적 음성에 미치는 영향. 말소리와음성과학, 9, 27-38.

Daniel R. Boone, Stephen C. McFarlane, Selley L. Von Berg (2007). 음성과음성치료(제7판, 황영진, 유재연, 정옥란 역). 서울: 시그마프레스. 